\title{
Evidence for PAH Removal Coupled to the First Steps of Anaerobic Digestion in Sewage Sludge
}

\author{
Glenda Cea-Barcia, Hélène Carrère, Jean Philippe Steyer, and Dominique Patureau
}

INRA, UR050, Laboratoire de Biotechnologie de l'Environnement, Avenue des Etangs, 11100 Narbonne, France

Correspondence should be addressed to Dominique Patureau; dominique.patureau@supagro.inra.fr

Received 7 September 2012; Revised 11 January 2013; Accepted 28 January 2013

Academic Editor: Claire Albasi

Copyright ( 2013 Glenda Cea-Barcia et al. This is an open access article distributed under the Creative Commons Attribution License, which permits unrestricted use, distribution, and reproduction in any medium, provided the original work is properly cited.

\begin{abstract}
Anaerobic degradation of polycyclic aromatic hydrocarbons has been brought to the fore, but information on removal kinetics and anaerobic degrading bacteria is still lacking. In order to explore the organic micropollutants removal kinetics under anaerobic conditions in regard to the methane production kinetics, the removal rate of 12 polycyclic aromatic hydrocarbons was measured in two anaerobic batch reactors series fed with a highly loaded secondary sludge as growth substrate. The results underscore that organic micropollutants removal is coupled to the initial stages of anaerobic digestion (acidogenesis and acetogenesis). In addition, the organic micropollutants kinetics suggest that the main removal mechanisms of these hydrophobic compounds are biodegradation and/or sequestration depending on the compounds.
\end{abstract}

\section{Introduction}

Polycyclic aromatic hydrocarbons (PAHs) are nowadays considered as environmental pollutants by environmental and health agencies because of their toxic, mutagenic, and carcinogenic effects on living organisms [1]. PAHs are mainly formed during human activities such as crude oil spillage, fossil fuel combustion, and gasoline leakage. Through the air and runoff after rainy events, the PAHs can deposit to soil, water bodies, and sewage system $[2,3]$. Due to their low water solubility and high octanol-water partition coefficients, these organic micropollutants $(\mu \mathrm{P})$ are mainly associated with hydrophobic compartments such as the organic matter in sewage sludge and river sediments or the lipids in biota, with levels between 0.001 and $10 \mu \mathrm{g} / \mathrm{g}_{\mathrm{DM}}$ for PAHs [4-6]. $\mu \mathrm{P}$ can be also sorbed irreversibly in a short time scale to the organic matter. This phenomenon named sequestration has been reported by different authors as one of the abiotic mechanisms of $\mu \mathrm{P}$ removal in digested sewage sludge and soils [7-9].

PAHs are known to be biodegraded under aerobic conditions $[10,11]$. However, most contaminated environments are anaerobic. In these environments, the anaerobic digestion can occur. Anaerobic digestion is a process whereby organic matter is broken down in the absence of oxygen into methane and carbon dioxide by naturally occurring microorganisms. The anaerobic digestion consists of four stages where different microbial populations participate: (1) hydrolysis, (2) acidogenesis, (3) acetogenesis, and (4) methanogenesis. The digestion process begins with the hydrolysis of insoluble organic polymers into monomers that are available for microorganisms. Acidogenesis is the step where these monomers are converted to carbon dioxide, hydrogen, and volatile fatty acids (acetic, propionic, butyric acids, etc.) by fermentative bacteria and then, in the acetogenesis stage, these metabolites are converted to acetic acid, hydrogen, and carbon dioxide by three different groups of bacteria (hydrogenic, homoacetogenic, and sulfatoreductive). Finally, the methanogenic microorganisms (strict anaerobic archaea) convert the acetic acid, hydrogen, $\mathrm{d}$ and carbon dioxide into methane $[12,13]$.

Recent results demonstrated that some PAHs [14-17] can be degraded under anaerobic conditions. It appears that this biodegradation is mainly coupled to methanogenic terminal oxidation processes $[18,19]$. A recent thermodynamic landscape study showed that the biodegradation of PAHs under methanogenic conditions is an exergonic process; it indicated also that PAHs could be degraded to acetate and $\mathrm{H}_{2}$ coupled to the conversion of these substrates to methane 
TABLE 1: Batch experiment setup. HLSS reactors series A and B with their respective nonspiked control HLSS reactors and the abiotic experiment.

\begin{tabular}{|c|c|c|c|}
\hline & HLSS reactors series A & HLSS reactors series B & HLSS abiotic reactors \\
\hline Number of reactors at day 0 & 6 reactors +1 control & 10 reactors +1 control & 4 reactors \\
\hline \multirow{5}{*}{ Date of analysis (number of reactors analyzed) } & Day $0(2)$ & Day 0 (2) & Day 0 (2) \\
\hline & Day 26 (1) & Day $8(2)$ & Day 54 (2) \\
\hline & Day 39 (1) & Day $13(2)$ & \\
\hline & Day 45 (1) & Day 18 (2) & \\
\hline & Day $54(1+1$ control $)$ & Day 34 (2+ 1 control $)$ & \\
\hline
\end{tabular}

as the optimal pathway [20]. In addition, observations that bromoethanesulfonic acid, an inhibitor of methanogenesis, inhibited partially the degradation of naphthalene and phenanthrene with the total elimination of methanogenic archaea and some bacteria, suggesting that the PAHs degradation could be associated not only to the methanogenesis stage but also to the first stages of anaerobic digestion [18].

On the other hand, microbial population and cometabolism pathway were found to influence $\mu \mathrm{P}$ removal. Indeed, an adapted inoculum is favorable to quantify $\mu \mathrm{P}$ degradation [17], suggesting that the abundance and diversity of $\mu \mathrm{P}$ degrading microorganisms and their associated metabolic routes are essential. PAHs are recalcitrant compounds, but their biodegradation is possible if combined with other substrate degradation and if syntrophic interactions occur. These interactions can thus be stimulated by the addition of a readily biodegradable growth substrate $[16,21]$. In fact, in the case where the sewage sludge is the growth substrate, it was demonstrated that the removal of PAHs by anaerobic digestion strongly varies as a function of sludge characteristics [7].

In order to further explore the $\mu \mathrm{P}$ biodegradation kinetics under anaerobic conditions in regard to the methane production kinetics, both total removal and removal rate of 12 PAHs were measured in different batch reactors series fed with secondary sludge as growth substrate.

\section{Materials and Methods}

2.1. Chemicals. All solvents were purchased from J.T.Baker. Fluorene (Fluo), phenanthrene (Phe), fluoranthene (Fluor), pyrene (Pyr), benzo(a)anthracene (B(a)A), Chrysene (Chrys), benzo(b)fluoranthene $(\mathrm{B}(\mathrm{b}) \mathrm{F})$, benzo(k)fluoranthene $(\mathrm{B}(\mathrm{k}) \mathrm{F})$, benzo(a)pyrene $(\mathrm{B}(\mathrm{a}) \mathrm{P})$, dibenzo(a,h)anthracene (DBA), benzo(g,h,i)perylene (B(ghi)P), and indeno(1,2,3,c, d)pyrene (Ind) were obtained from Dr. Ehrenstorfer GmbH. The spiking mix at $100 \mathrm{mg} / \mathrm{L}$ was prepared in acetonitrile except for indeno(1,2,3,c,d)pyrene $(20 \mathrm{mg} / \mathrm{L})$. The $10 \mathrm{mg} / \mathrm{L}$ HPLC standard solution of PAHs in acetonitrile was provided by Dr. Ehrenstorfer GmbH. For quantification, the standard solutions were diluted to obtain 6 calibration levels from 10 to $1000 \mu \mathrm{g} / \mathrm{L}$ in acetonitrile. Standards were stored at $-20^{\circ} \mathrm{C}$.

2.2. Sludge Samples. The experiments were carried out using a highly loaded secondary sludge sample (HLSS) which was sampled in the biological aerobic unit of an urban plant treating 250000 person equivalent $(\mathrm{PE})$ with a very low sludge retention time ( 0.4 day); it was, therefore, not stabilized. Prior to its direct use, HLSS was stored at $-20^{\circ} \mathrm{C}$.

2.3. $\mu$ P-Adapted Anaerobic Inoculum. The inoculum (biomass adapted to $\mu \mathrm{P}$ ) was produced in a semicontinuous stirred lab-scale reactor of $5 \mathrm{~L}$. It was fed with HLSS diluted with deionized water to reach $24 \pm 5 \mathrm{~g}_{\mathrm{COD}} / \mathrm{L}$ which was spiked with a mix of 12 PAHs (Section 2.1) at $5 \mu \mathrm{g} / \mathrm{g}_{\mathrm{DM}}$ for each PAH except for indeno $(1,2,3, \mathrm{c}, \mathrm{d})$ pyrene $\left(1 \mu \mathrm{g} / \mathrm{g}_{\mathrm{DM}}\right)$. This reactor was inoculated with a digested sludge coming from a mesophilic anaerobic industrial reactor adapted to $\mathrm{PAH}-$ polluted sludge. Temperature was regulated at $35^{\circ} \mathrm{C}$ using hot water circulation in the external jacket. The feed was stored at $4^{\circ} \mathrm{C}$. The reactor was operated at a retention time of 20 days and an organic load of $1.2 \pm 0.2 \mathrm{~g}_{\mathrm{COD}} / \mathrm{L} /$ day. The $\mathrm{pH}$ and the biogas volumetric production were monitored on line. Once a week, composite samples were taken from the feeding and outlet tanks to measure the chemical parameters and $\mu \mathrm{P}$ concentrations. The adapted-to- $\mu \mathrm{P}$ digested sludge was kept at $35^{\circ} \mathrm{C}$ until its use for batch experiments as inoculum.

2.4. Batch Experiments. The anaerobic digestion of HLSS in batch conditions was performed using $300 \mathrm{~mL}$ plasma bottles containing $250 \mathrm{~mL}$ of a defined mixture of sewage sludge (substrate) and inoculum (biomass). The bottles were stirred $(100 \mathrm{rpm})$ and maintained at $35^{\circ} \mathrm{C}$. For these experiments, the sludge to inoculum ratio was equal to $0.5 \mathrm{~g}$ COD $/ \mathrm{g}_{\text {Organic Matter }}$. The inoculum was concentrated from 8 to $18 \mathrm{~g} / \mathrm{L}$ of dry matter (DM) to obtain a mixture with a total DM of $20 \mathrm{~g} / \mathrm{L}$. The mixture was spiked at $15 \mu \mathrm{g} / \mathrm{g}_{\mathrm{DM}}$ for each $\mathrm{PAH}$ and $3 \mu \mathrm{g} / \mathrm{g}_{\mathrm{DM}}$ for Ind. Two reactors series (A and B) were carried out (Table 1). The series A was performed in order to observe the overall activities with DM removal, biogas production, and $\mu \mathrm{P}$ removal. Based on the results of series $\mathrm{A}$, indicating that $\mu \mathrm{P}$ removals occur before the production of methane, the series B was later performed. This series was carried out in duplicate to accurately analyze the concomitant evolution of $\mu \mathrm{P}$ and acetate during the first steps of the anaerobic digestion. At different reaction times, one reactor (series A) or two reactors (series $\mathrm{B}$ ) were stopped to measure the total $\mu \mathrm{P}$ concentration over time (Table 1 ). Indeed, to quantify the $\mu \mathrm{P}$, it is necessary to get a large amount of dry matter to extract them in duplicate. The two series were conducted under 
the same initial conditions, but for the series B, sampling frequency was higher in order to observe more precisely the $\mu \mathrm{P}$ kinetics and the anaerobic digestion kinetics. The initial $\mu \mathrm{P}$ concentration was determined also in duplicate for both series. In parallel, several control reactors were realized: nonspiked HLSS reactors (one per series) and HLSS abiotic reactors (Table 1). These abiotic control reactors were prepared by autoclaving the mixture-containing plasma bottles at $121^{\circ} \mathrm{C}$ for $20 \mathrm{~min}$.

Biogas volume was measured by liquid displacement and its composition was measured by gas chromatography. For all reactors, volumes of biogas were reported to the COD introduced in the bottle. In addition, volatile fatty acids ((VFAs), g/L) production was followed in all reactors series.

2.5. Analytical Methods. Chemical oxygen demand ((COD), $\left.\mathrm{g}_{\mathrm{O}_{2}} / \mathrm{L}\right)$, dry matter $\left((\mathrm{DM}), \mathrm{g}_{\mathrm{DM}} / \mathrm{L}\right)$ and organic/volatile matter ((OM), $\left.\mathrm{g}_{\mathrm{OM}} / \mathrm{L}\right)$ were determined both at the beginning and end of the experiments. DM in total mixtures was measured by weighing the sample after heating at $105^{\circ} \mathrm{C}$ during $24 \mathrm{~h}$ and the $\mathrm{OM}$ after heating at $550^{\circ} \mathrm{C}$ during $2 \mathrm{~h}$. The chemical oxygen demand COD was determined thanks to Merck Spectroquant kits, according to the ISO 15705 . The samples were diluted to be in the range $0-1500 \mathrm{mg}_{\mathrm{COD}} / \mathrm{L}$. The VFAs acetate, propionate, isobutyrate, butyrate, isovalerate, and valerate concentrations were determined in dissolved/colloidal phase by gas chromatography (GC800, Fisons Instruments).

At different reaction time, the total volume of each reactor (series A and B) was freeze-dried in order to extract the PAHs according to the method developed by Trably et al. [22]. The extractions were done in duplicate. The PAHs quantification in the extracts was previously described [22]. These measurements gave the total $\mu \mathrm{P}$ concentration in $\mu \mathrm{g}_{\mu \mathrm{P}} / \mathrm{g}_{\mathrm{DM}}$.

2.6. Data Analysis. The $\mu \mathrm{P}$ removal rates and the accumulation rates of methane and acetate were used to correlate the $\mu \mathrm{P}$ removal kinetics to the anaerobic digestion steps. $\mu \mathrm{P}$ removal rates $\left(r_{\mu \mathrm{P}}\right)$ were calculated using discrete points by difference of concentrations between two reactors (series A) or two pairs of reactors (series B) and divided by their respective difference of reaction times. These parameters were expressed in $\mu \mathrm{g} / \mathrm{L} /$ day. In the case of series $\mathrm{B}$, the $r_{\mu \mathrm{P}}$ were plotted in a boxplot graph which is a descriptive representation of independent data. Methane production rate $\left(r_{\mathrm{CH}_{4}}\right)$ and acetate accumulation rate $\left(r_{\text {acetate }}\right)$ were calculated with the production of methane or accumulation of acetate in a range of time expressed in $\mathrm{mL}_{\mathrm{CH}_{4}} / \mathrm{g}_{\mathrm{COD}} /$ day and $\mathrm{g} / \mathrm{L} /$ day, respectively. The methane production first-order kinetic constant $\left(k_{\mathrm{CH}_{4}}\right.$, day $\left.{ }^{-1}\right)$ was determined as following:

$$
V_{\mathrm{CH}_{4}}(t)=V_{\mathrm{CH}_{4}}\left(t_{f}\right)\left(1-\exp \left(-k_{\mathrm{CH}_{4}} t\right)\right),
$$

where $\left(V_{\mathrm{CH}_{4}}(t)\right.$ is methane volume; $V_{\mathrm{CH}_{4}}\left(t_{f}\right)$ is maximum methane production; $k_{\mathrm{CH}_{4}}$ is first-order constant; $t$ is time).

The total $\mu \mathrm{P}$ concentrations $(\mu \mathrm{g} / \mathrm{L})$ were calculated using the measured concentrations $\left(\mu \mathrm{g} / \mathrm{g}_{\mathrm{DM}}\right)$ and the $\mathrm{DM}$ concentrations of each reactor. For the abiotic reactors, the $\mu \mathrm{P}$

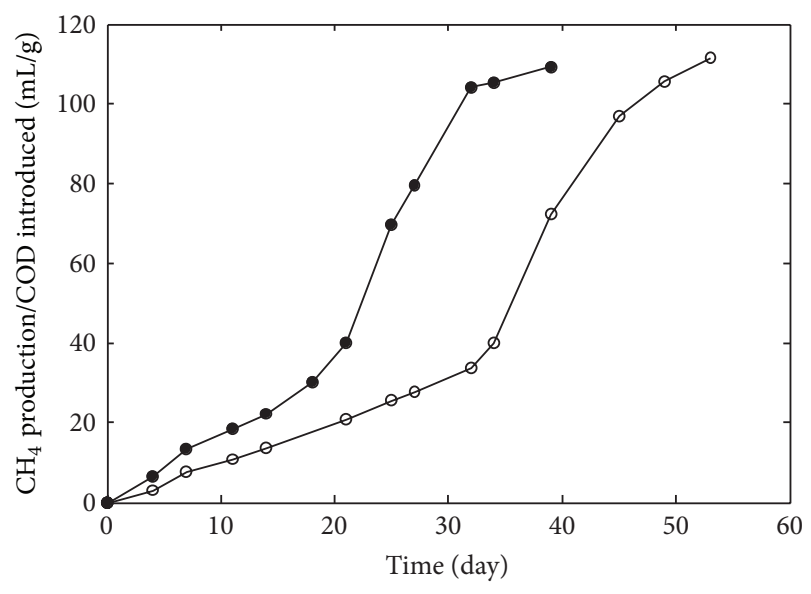

FIGURE 1: Methane production over time in un-spiked and spiked HLSS reactors. (•) nonspiked HLSS, $k_{\mathrm{CH}_{4}} 0.12$ day ${ }^{-1}$. (०) spiked HLSS, $k_{\mathrm{CH}_{4}} 0.067 \pm 0.003$ day $^{-1}$.

removals were calculated on the basis of mass balance between the initial concentration of $\mu \mathrm{P}$ in reactors (day 0 ) and the concentration in reactors stopped at the end of incubation.

\section{Results and Discussion}

3.1. Production of $\mu$ P-Adapted Anaerobic Digested Sludge. The semicontinuous anaerobic digestion of spiked HLSS was carried out to produce a homogeneous $\mu \mathrm{P}$-adapted inoculum for the batch experiments, as previously described in the Section 2.3. All the results were previously published by Barret et al. [7]. During the anaerobic digestion, total COD and DM were reduced by $67 \pm 7 \%$ and $58 \pm 10 \%$, respectively. $\mu \mathrm{P}$ removals for all compounds ranged from $48 \%$ (Ind) to $85 \%$ (Fluo). Since $\mu \mathrm{P}$ volatilization was undetectable in the reactor, it was assumed that the calculated removals included biodegradation and sequestration $[7,9]$; therefore, a $\mu \mathrm{P}$ adapted inoculum was obtained.

3.2. Removal of $\mu P$ in HLSS Anaerobic Batch Reactors. In order to describe the $\mu \mathrm{P}$ removal kinetics under anaerobic conditions, the total $\mu \mathrm{P}$ concentrations, DM and OM concentrations, biogas production and composition were measured over time in one of the HLSS batch reactors series (series A) and its corresponding nonspiked HLSS reactor.

In both reactors, the anaerobic digestion was stable with methane content in biogas at about $80 \%$ and $\mathrm{pH}$ 7. In the case of spiked reactors series, the lag phase lasted approximately twice as long as the lag phase of nonspiked reactors (Figure 1). This could indicate that there was an effect of the $\mu \mathrm{P}$ concentrations on the microbial population adaptation. However, the maximum volume of biogas was similar in both spiked reactors series and nonspiked reactor, which means that there was no inhibitory effect of the $\mu \mathrm{P}$ on the overall metabolism of anaerobic digestion. In contrast, a recent study showed that the anaerobic digestion in continuous reactors of wastewaters from industrial processes that contain very high 
TABLE 2: $\mu \mathrm{P}$ maximum removal rates in biotic and spiked HLSS reactors (series A). Comparison with the $\mu \mathrm{P}$ removal rates calculated in the semicontinuous reactor at steady states [7].

\begin{tabular}{lcc}
\hline Compound & $\begin{array}{c}\text { HLSS maximum } \\
\text { removal rates } \\
(\mu \mathrm{g} / \mathrm{L} / \text { day })\end{array}$ & $\begin{array}{c}\text { Semicontinuous } \\
\text { reactor removal } \\
\text { rates }(\mu \mathrm{g} / \mathrm{L} / \text { day })\end{array}$ \\
\hline Fluorene & $1.8 \pm 0.1$ & $1.8 \pm 1.1$ \\
Phenanthrene & $3.0 \pm 0.3$ & $4.0 \pm 1.4$ \\
Fluoranthene & $2.7 \pm 0.7$ & $3.1 \pm 0.9$ \\
Pyrene & $2.2 \pm 0.5$ & $3.6 \pm 1.1$ \\
Benzo(a)anthracene & $2.2 \pm 0.7$ & $4.4 \pm 1.4$ \\
Chrysene & $2.1 \pm 0.8$ & $3.3 \pm 0.9$ \\
Benzo(b)fluoranthene & $2.7 \pm 1.0$ & $3.9 \pm 1.4$ \\
Benzo(k)fluoranthene & $3.0 \pm 0.8$ & $3.5 \pm 0.9$ \\
Benzo(a)pyrene & $1.7 \pm 1.1$ & $1.7 \pm 0.6$ \\
Dibenzo(a,h)anthracene & $2.8 \pm 1.0$ & $3.3 \pm 0.7$ \\
Benzo(g,h,i)perylene & $1.6 \pm 0.7$ & $3.3 \pm 1.0$ \\
Indeno(1,2,3,c,d)pyrene & $0.4 \pm 0.2$ & $0.4 \pm 0.2$ \\
\hline
\end{tabular}

concentrations of $\mu \mathrm{P}$ (included PAHs) is inhibited with concentrations around $16 \mathrm{~g}_{\mathrm{COD}, \mu \mathrm{P}} / \mathrm{L}[23]$. This result suggests that a certain $\mu \mathrm{P}$ level could have an inhibitory effect on the anaerobic digestion. To compare, in our case, the initial COD concentration was $0.001 \mathrm{~g}_{\mathrm{COD}, \mathrm{PAH}} / \mathrm{L}$, which is much lower than the $\mu \mathrm{P}$ level of Puyol et al. [23].

Therefore, even if no inhibition occurred on the overall metabolism, the methane first-order constant $\left(k_{\mathrm{CH}_{4}}\right)$ decreased by $44 \%$ in the case of spiked reactors (Figure 1 ). The $k_{\mathrm{CH}_{4}}$ values of the nonspiked reactors are $40 \%$ lower than those calculated using the methane produced from a secondary sludge in batch conditions published by Mottet et al. [24]. These lower $k_{\mathrm{CH}_{4}}$ values of the nonspiked reactors may be explained by either our initial conditions with a lower sludge to inoculum ratio and a high DM initial concentration, or a lower methanogenic activity of our $\mu \mathrm{P}$-adapted inoculum that was maintained a long time without feeding before use. However, these results show that the presence of $\mu \mathrm{P}$ slows down the overall anaerobic digestion kinetic but leads to the same methane potential. This may be due to either the expression of different metabolic routes to degrade the substrate and the $\mu \mathrm{P}$, or to the deviation of electron fluxes towards $\mu \mathrm{P}$, or to the $\mu \mathrm{P}$ toxicity/inhibition on some microbial groups.

$r_{\mu \mathrm{P}}$ are presented in Table 2 and compared with the values obtained in the semicontinuous reactor. The $r_{\mu \mathrm{P}}$ are similar between the two culture conditions except for B(a)A and $\mathrm{B}$ (ghi)P with higher values under a semicontinuous condition. This means that the microbial potential developed to remove the $\mu \mathrm{P}$ in the semicontinuous reactor was maintained and expressed itself during the batch experiment.

Fluor and DBA removals rates $\left(r_{\mathrm{Fluor}}, r_{\mathrm{DBA}}\right)$ together with methane production rate $\left(-r_{\mathrm{CH}_{4}}\right)$ over time are presented in Figure 2. In all cases, the $\mu \mathrm{P}$ removal rates increase during the first 39 days of reaction, including the lag phase and the beginning of the exponential phase, and then decrease to

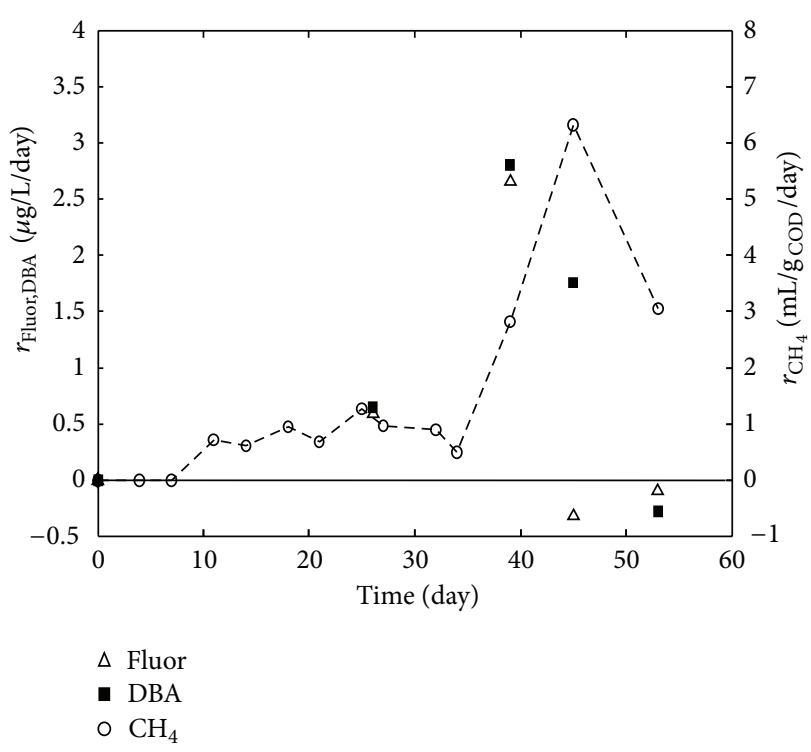

Figure 2: Removal kinetics of Fluor and DBA coupled to methane production kinetic in HLSS reactors (series A). The initial $\mu \mathrm{P}$ concentration was measured in duplicate. One reactor was stopped at different sampling times.

zero. This behavior was also found for the other 10 PAHs, and most of them have the same profile as fluor, where the $r_{\mu \mathrm{P}}$ decreased to zero after 45 days. However, negative values of $r_{\mu \mathrm{P}}$ were obtained at 45 and 53 days. This could be due to concentration variability between each reactor.

These results suggest that the reduction of $\mu \mathrm{P}$ concentration is not only linked to methanogenesis, but it may be also due to abiotic processes at the beginning of the lag phase such as volatilization, adsorption to internal glass surface of the bottles, and/or sequestration [9, 25]. Considering these results, abiotic reactors and a second HLSS reactors series (series B) were carried out to precisely describe the $\mu \mathrm{P}$ degradation kinetics during the early stages of anaerobic digestion.

3.3. $\mu P$ Degradation Kinetics during HLSS Anaerobic Batch Reactors. A second HLSS reactors series (series B) was carried out according to Section 2.4 to better describe the $\mu \mathrm{P}$ removal kinetics until the beginning of the exponential phase of methane production.

The VFAs concentration and methane production were followed in each reactor. Both VFAs and methane kinetics were similar in all reactors. For most of the $\mu \mathrm{P}$, their concentrations were approximately constant until day 8 with no significant differences between the two values of concentrations of each pair of reactors, finding the highest differences for Chrys (4\%) and B(ghi)P (5\%). In the case of Fluo, Phe, and Fluor, important losses were found during the first 8 days mainly at day 1 of incubation. In this period, no important acetate and methane productions were observed, indicating that these compounds could have been removed by abiotic processes like volatilization, sequestration in the sludge matrix, and adsorption on glass bottles. This behavior was 
confirmed by the abiotic reactors results. All abiotic controls had a very low methane and VFAs production, indicating no microbial activity. The most important abiotic losses were found for Fluo, Phe, and Fluor $(33 \pm 0.6,8 \pm 1$, and $3 \pm 2$ ) after 54 days. These results are similar with those of Chang et al. [15], who found abiotic losses after 60 and 84 days of incubation with spiked batch reactors of 7\% Fluo and 5\% Phe.

Regarding the physicochemical characteristics of these compounds and according to the model proposed by Barret et al. [26], in the cases of Fluo, Phe, and Fluor, their highest volatility and lowest $\operatorname{logKow}(4.18,4.57$, and 5.1$)$ suggest that the main removal mechanism at day 1 of incubation could be the volatilization. However, the methane production at day 1 is negligible, and thus the liquid-gas transfer is low. This suggests that the drop in the concentration is not only due to volatilization but also to sludge sequestration or glass adsorption.

Different $r_{\mu \mathrm{P}}, r_{\mathrm{CH}_{4}}$, and $r_{\text {acetate }}$ were calculated according to Section 2.6. $r_{\mu \mathrm{P}}$ ranged from $4 \pm 2 \mu \mathrm{g} / \mathrm{L} /$ day (Fluo) to $1 \pm$ $0.5 \mu \mathrm{g} / \mathrm{L} /$ day (Ind) for PAHs. Maximal $r_{\text {acetate }}$ were $0.039 \pm$ $0.006 \mathrm{~g}_{\mathrm{COD}} / \mathrm{L} /$ day and are comparable to the values found in the literature [24]. Figure 3 shows that the kinetic of $r_{\mathrm{DBA}}$ is coupled to that of $r_{\text {acetate }}$ and $r_{\mathrm{CH}_{4}}$. Indeed, $r_{\mathrm{DBA}}$ increases when $r_{\text {acetate }}$ increases. When acetate is consumed to produce methane with a sharp decrease of $r_{\text {acetate }}$, the $r_{\mathrm{DBA}}$ decreases also. This behavior was also found for Fluo, B(b)F, B(k)F, and $\mathrm{B}$ (ghi) $\mathrm{P}$ and in the other six compounds, although with different kinetics. In the case of Pyr, $r_{\mu \mathrm{P}}$ started to increase after 18 days. Furthermore, Fluor, Phe, Chrys, B(a)A, B(a)P, and Ind maintained maximum values of $r_{\mu \mathrm{P}}$ even at the beginning of the exponential phase (18 and 34 days). These results reveal a relation between the first stages of anaerobic digestion (acidogenesis/acetogenesis) and the removal of $\mu$ P.

\section{Conclusions}

The anaerobic degradation of PAHs in sewage sludge has already been studied but mainly under simplified batch experiments or using complex medium in continuous reactors. Unlike the continuous reactors, our methodology allows to observe the different steps of anaerobic digestion and to link these steps to the removal of $\mu \mathrm{P}$. The results show a strong evidence of relation between the initial stages of anaerobic digestion (acidogenesis and acetogenesis) and $\mu \mathrm{P}$ removal in HLSS reactors. This relation was demonstrated by concomitant evolution of $r_{\mu \mathrm{P}}$ and $r_{\text {acetate }}$. On the other hand, no complete inhibition of anaerobic digestion was observed in the presence of $\mu \mathrm{P}$ with a production of methane similar to the production without $\mu \mathrm{P}$, but lag phases occurred implying microorganisms adaptation to the $\mu \mathrm{P}$ load and also the methane production kinetic was slowed down. The evidence of microorganisms adaptation to $\mu \mathrm{P}$ concentrations supports the results that linked the first stages of anaerobic digestion with the $\mu \mathrm{P}$ removal. In addition, the results show that the $\mu \mathrm{P}$ removals are also linked to two important abiotic processes depending on the compounds: volatilization (mainly the lowmolecular-weight PAHs) and sequestration. This work provided important outcomes to better understand the PAHs anaerobic removal, to know its kinetics, and to identify the

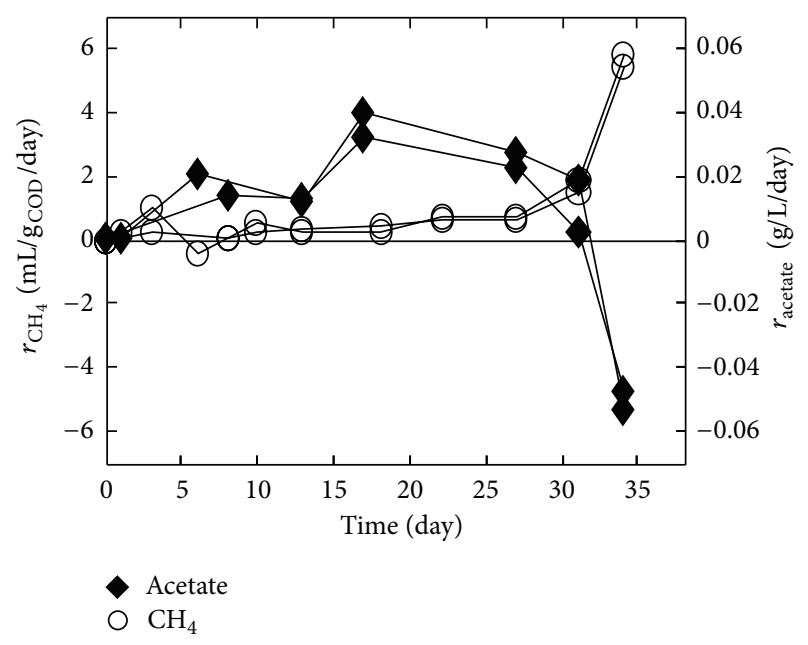

(a)

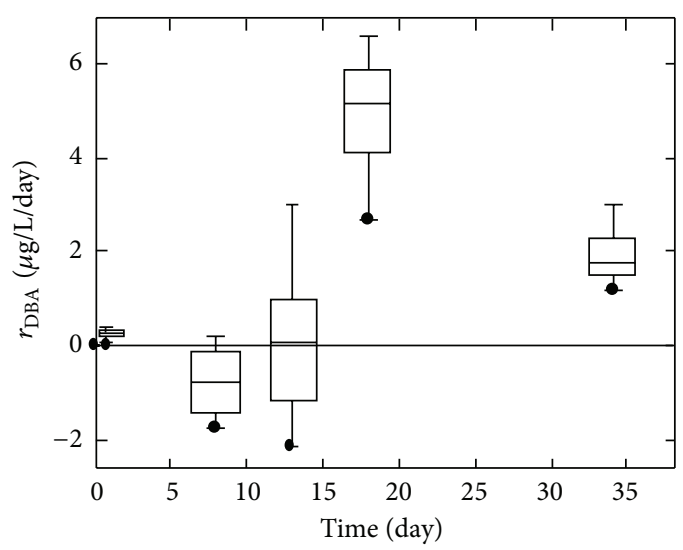

(b)

FIgURE 3: Removal kinetic of DBA coupled to methane production kinetic and acetate accumulation kinetic during the anaerobic digestion of HLSS (series $\mathrm{B}$ ). The initial $\mu \mathrm{P}$ concentrations were measured in duplicate. Two reactors were stopped at different sampling times.

most important parameters, such as cometabolic activity, for optimizing their depletion.

\section{Acknowledgments}

The authors gratefully acknowledge CONICYT (Comisión Nacional de Investigación Científica y Tecnológica), Government of Chili and CROUS International, Government of France, and the Agence de l'Environnement et de la Maîtrise de l'Energie (ADEME-Convention no. 0906C0008 from the National Program of Research on Endocrine Disruptors (PNRPE)) for their financial support that made this study feasible.

\section{References}

[1] S. K. Samanta, O. V. Singh, and R. K. Jain, "Polycyclic aromatic hydrocarbons: environmental pollution and bioremediation," Trends in Biotechnology, vol. 20, no. 6, pp. 243-248, 2002. 
[2] Y. Wada, T. Ozaki, and M. Muraoka, "Characteristics of Benzo (a) Pyrene in highway runoff pollution," in Proceedings of the 10th International Conference on Urban Drainage, Copenhagen, Denmark, August 2005.

[3] A. Welker, "Fate and behavior of selected organic substances in the urban drainage system," in Proceedings of the 10th International Conference on Urban Drainage, Copenhagen, Denmark, August 2005.

[4] E. Abad, K. Martínez, C. Planas, O. Palacios, J. Caixach, and J. Rivera, "Priority organic pollutant assessment of sludges for agricultural purposes," Chemosphere, vol. 61, no. 9, pp. 13581369, 2005.

[5] M. Blanchard, M. J. Teil, D. Ollivon, L. Legenti, and M. Chevreuil, "Polycyclic aromatic hydrocarbons and polychlorobiphenyls in wastewaters and sewage sludges from the Paris area (France)," Environmental Research, vol. 95, no. 2, pp. 184-197, 2004.

[6] D. Bodzek and B. Janoszka, "Comparison of polycyclic aromatic compounds and heavy metals contents in sewage sludges from industrialized and non-industrialized region," Water, Air, and Soil Pollution, vol. 111, no. 1-4, pp. 359-369, 1999.

[7] M. Barret, G. C. Barcia, A. Guillon, H. Carrère, and D. Patureau, "Influence of feed characteristics on the removal of micropollutants during the anaerobic digestion of contaminated sludge," Journal of Hazardous Materials, vol. 181, no. 1-3, pp. 241-247, 2010.

[8] G. L. Northcott and K. C. Jones, "Partitioning, extractability, and formation of nonextractable PAH residues in soil. 1. Compound differences in aging and sequestration," Environmental Science and Technology, vol. 35, no. 6, pp. 1103-1110, 2001.

[9] K. T. Semple, A. W. J. Morriss, and G. I. Paton, "Bioavailability of hydrophobic organic contaminants in soils: fundamental concepts and techniques for analysis," European Journal of Soil Science, vol. 54, no. 4, pp. 809-818, 2003.

[10] X. Y. Lu, T. Zhang, and H. H. P. Fang, "Bacteria-mediated PAH degradation in soil and sediment," Applied Microbiology and Biotechnology, vol. 89, no. 5, pp. 1357-1371, 2011.

[11] S. Y. Yuan, S. H. Wei, and B. V. Chang, "Biodegradation of polycyclic aromatic hydrocarbons by a mixed culture," Chemosphere, vol. 41, no. 9, pp. 1463-1468, 2000.

[12] B. K. Ahring, "Biomethanation I," in Advances in Biochemical Engineering/Biotechnology, T. Scheper, Ed., p. 220, Springer, Berlin, Germany, 2003.

[13] D. J. Batstone, J. Keller, I. Angelidaki et al., "The IWA anaerobic digestion model no. 1 (ADM1)," Water Science and Technology, vol. 45, no. 10, pp. 65-73, 2002.

[14] A. Bernal-Martinez, D. Patureau, J. P. Delgenès, and H. Carrère, "Removal of polycyclic aromatic hydrocarbons (PAH) during anaerobic digestion with recirculation of ozonated digested sludge," Journal of Hazardous Materials, vol. 162, no. 2-3, pp. 1145-1150, 2009.

[15] B. V. Chang, S. W. Chang, and S. Y. Yuan, "Anaerobic degradation of polycyclic aromatic hydrocarbons in sludge," Advances in Environmental Research, vol. 7, no. 3, pp. 623-628, 2003.

[16] D. Dionisi, L. Bertin, L. Bornoroni, S. Capodicasa, M. P. Papini, and F. Fava, "Removal of organic xenobiotics in activated sludges under aerobic conditions and anaerobic digestion of the adsorbed species," Journal of Chemical Technology and Biotechnology, vol. 81, no. 9, pp. 1496-1505, 2006.

[17] E. Trably, D. Patureau, and J. P. Delgenes, "Enhancement of polycyclic aromatic hydrocarbons removal during anaerobic treatment of urban sludge," Water Science and Technology, vol. 48, no. 4, pp. 53-60, 2003.

[18] W. Chang, Y. Um, and T. R. P. Holoman, "Polycyclic aromatic hydrocarbon (PAH) degradation coupled to methanogenesis," Biotechnology Letters, vol. 28, no. 6, pp. 425-430, 2006.

[19] D. M. Jones, I. M. Head, N. D. Gray et al., "Crude-oil biodegradation via methanogenesis in subsurface petroleum reservoirs," Nature, vol. 451, no. 7175, pp. 176-180, 2008.

[20] J. Dolfing, A. Xu, N. D. Gray, S. R. Larter, and I. M. Head, "The thermodynamic landscape of methanogenic PAH degradation," Microbial Biotechnology, vol. 2, no. 5, pp. 566-574, 2009.

[21] Y. Zhong, T. Luan, X. Wang, C. Lan, and N. F. Y. Tam, "Influence of growth medium on cometabolic degradation of polycyclic aromatic hydrocarbons by Sphingomonas sp. strain PheB4," Applied Microbiology and Biotechnology, vol. 75, no. 1, pp. 175186, 2007.

[22] E. Trably, N. Delgènes, D. Patureau, and J. P. Delgènes, "Statistical tools for the optimization of a highly reproducible method for the analysis of polycyclic aromatic hydrocarbons in sludge samples," International Journal of Environmental Analytical Chemistry, vol. 84, no. 13, pp. 995-1008, 2004.

[23] D. Puyol, V. M. Monsalvo, N. Garcia-Mancha, A. F. Mohedano, and J. J. Rodriguez, "Anaerobic biological treatment of wastewaters from used oil recovery," in Proceedings of the 5th European Bioremediation Conference, p. 189, Crete, Greece, 2011.

[24] A. Mottet, J. P. Steyer, S. Déléris, F. Vedrenne, J. Chauzy, and H. Carrère, "Kinetics of thermophilic batch anaerobic digestion of thermal hydrolysed waste activated sludge," Biochemical Engineering Journal, vol. 46, no. 2, pp. 169-175, 2009.

[25] S. M. Bamforth and I. Singleton, "Bioremediation of polycyclic aromatic hydrocarbons: current knowledge and future directions," Journal of Chemical Technology and Biotechnology, vol. 80, no. 7, pp. 723-736, 2005.

[26] M. Barret, H. Carrère, E. Latrille, C. Wisniewski, and D. Patureau, "Micropollutant and sludge characterization for modeling sorption equilibria," Environmental Science and Technology, vol. 44, no. 3, pp. 1100-1106, 2010. 

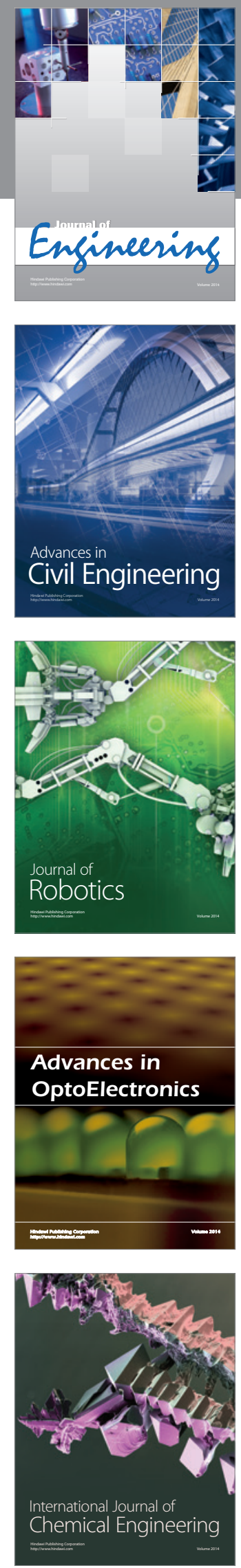

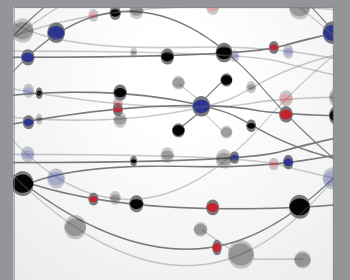

The Scientific World Journal
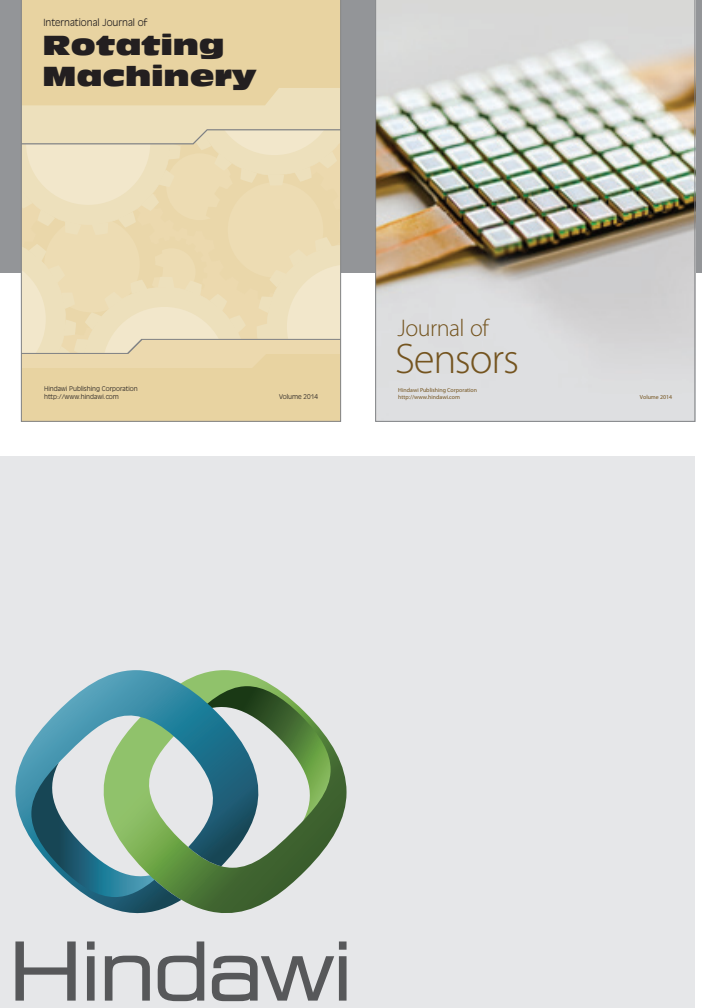

Submit your manuscripts at http://www.hindawi.com
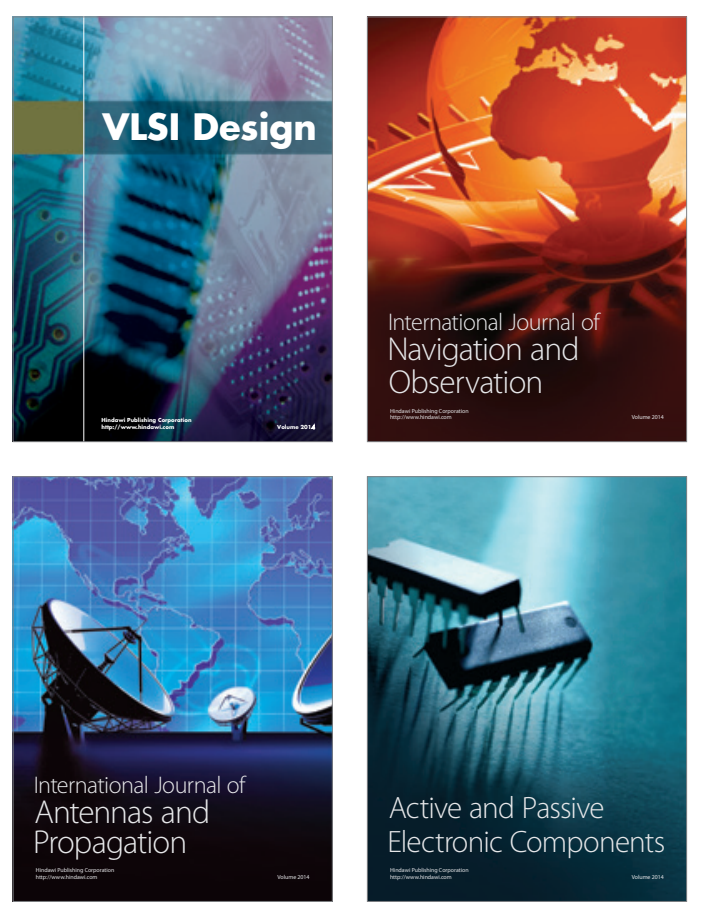
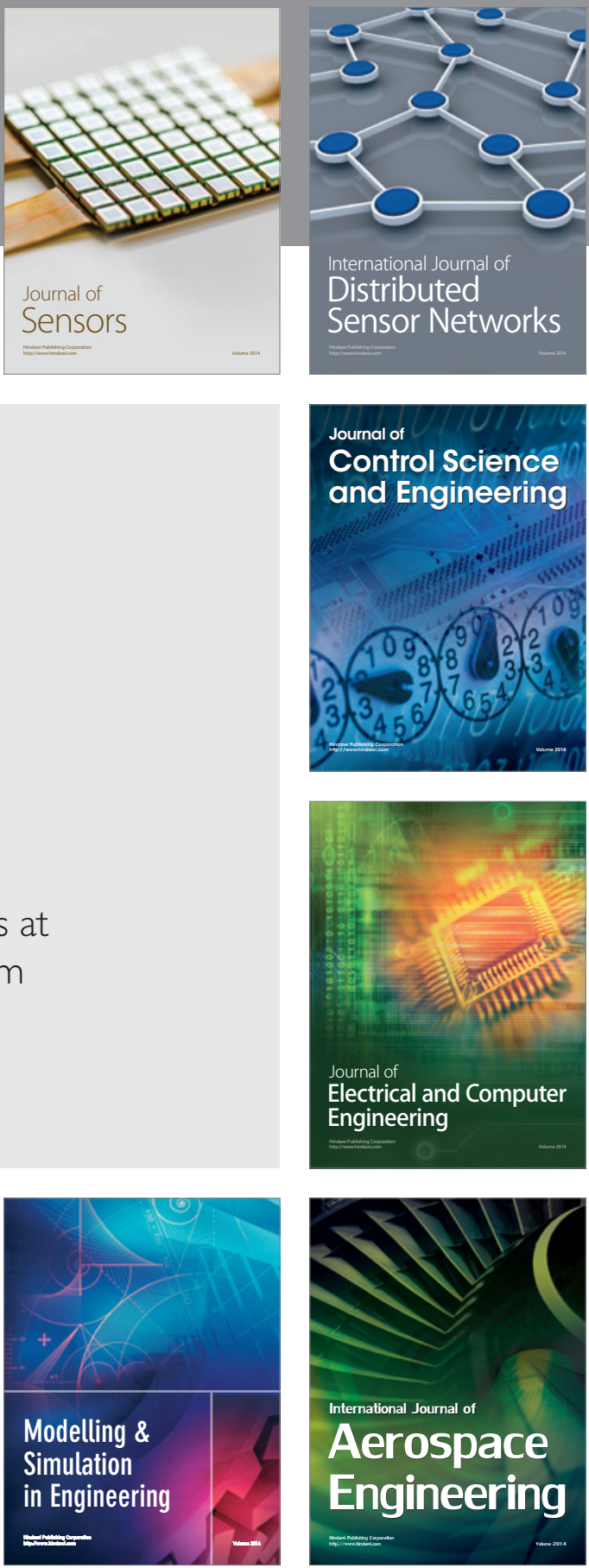

Journal of

Control Science

and Engineering
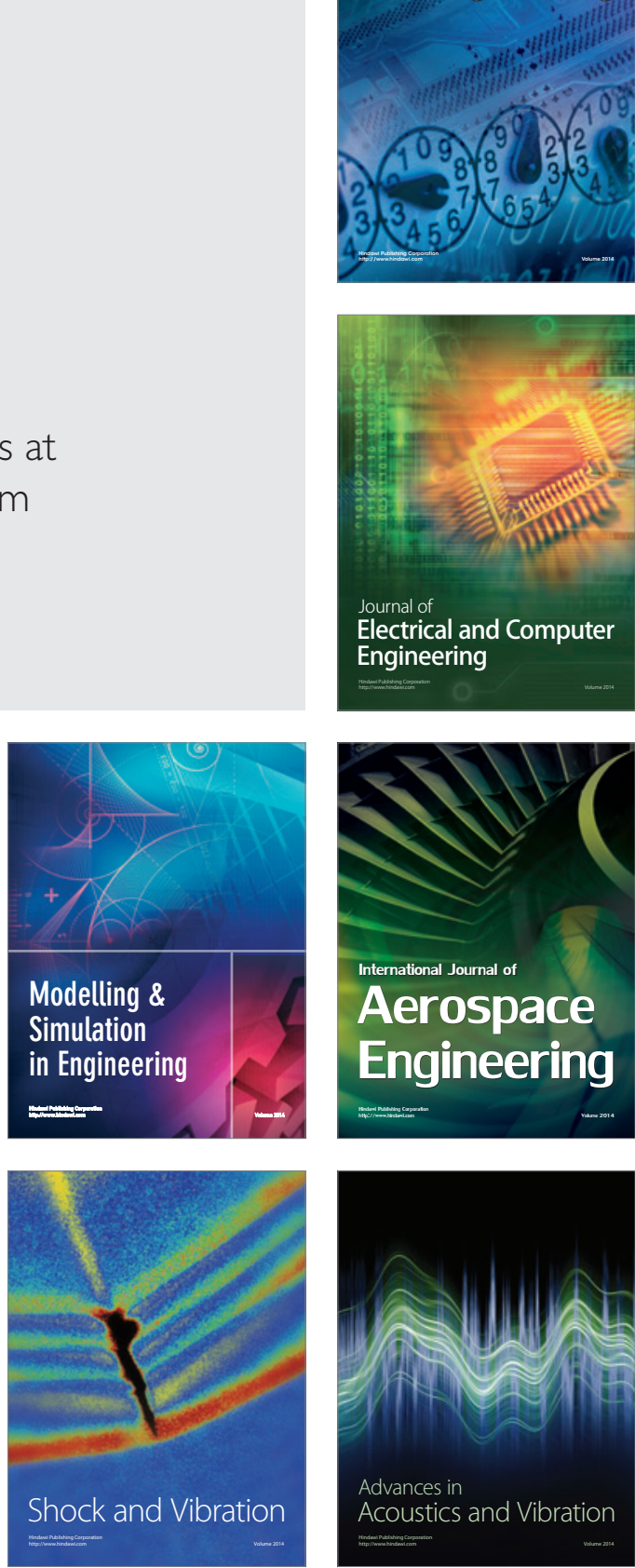